\title{
REPRODUCTIVE FAILURE OF MICE CAUSED BY PINE NEEDLE INGESTION
}

\author{
FU-HO C. CHOW, KATHLEEN J. HANSON, \\ D. W. HAMAR AND R. H. UDALL \\ Department of Pathology, College of Veterinary Medicine and Biomedical Sciences, \\ Colorado State University, Fort Collins, Colorado
}

(Received 4th February 1972, accepted 18th February 1972)

Colorado residents of long standing can recall the legend that Indian women used to take an aqueous extract of pine needles to induce abortion. The effects of pine needle ingestion on pregnancy of cattle and mice have been reported by Bruce (1927), MacDonald (1952), Deem, Osborn \& Maag (1959, unpublished data reported by Faulkner, 1968), Allen \& Kitts (1961), and Cook \& Kitts (1964), but the active agent and the effect on reproduction have not been defined. The object of this investigation was to isolate the agent which affects reproduction.

Three fractions (volatile, water-soluble and acetone-soluble) were prepared from needles of yellow pine (Pinus ponderosa) collected from Rist Canyon, west of Fort Collins, Colorado, and stored in plastic bags at $-20^{\circ} \mathrm{C}$. Fractions were prepared as follows.

1. Volatile fraction. The needles were macerated in distilled water using a blender and then steam-distilled at atmospheric pressure for $6 \mathrm{hr}$. The volatile material was extracted from the distillate by petroleum ether following the methods of Sakai, Maarse, Kepner, Jennings \& Longhurst (1967).

2. Water-soluble fraction. The needles were cut into 1 inch long segments and macerated in a blender with distilled water. The liquid portion was decanted into a Buchner funnel and the residue extracted twice with additional water. The final slurry, liquid and solids, was transferred to the funnel for filtration and the solids were thoroughly washed with water. The filtrate and washings were combined, freeze-dried and designated as aqueous fraction.

3. Acetone-soluble fraction. The solids, a green mass from the water extraction, were transferred into the blender and extracted with acetone following the procedure used for water extraction. The filtrate and acetone washings were combined, freeze-dried and designated as acetone fraction. The final solid residue was yellowish fibrous material.

The water-soluble and acetone-soluble fractions are designated the aqueous and acetone fractions, respectively, in the text. The amount of pine needle fraction added to the basal feed, Purina Mouse Chow, was calculated according to the amount of each fraction extracted. For example, a 2:1 ration means that an amount of substance equivalent to $2 \mathrm{~g}$ of pine needles was added to $1 \mathrm{~g}$ of feed.

To test the effect of various fractions on uterine growth, 21-day-old female 
mice of GFW strain (Carworth, New York), weighing 11 to $13 \mathrm{~g}$, were given the experimental feeds. After 4 days, the mice were killed by $\mathrm{CO}_{2}$ and the uteri were removed and weighed, following the method of Emmens (1969). The results are tabulated in Table 1. The acetone fraction at a level equivalent to 2:1 was not palatable and at a 1:1 level had no effect. The volatile fraction in high concentration had some effect, but the aqueous fraction caused a pronounced depression of uterine growth. Mice fed the aqueous ration at a 2:1 level developed diarrhoea and tympanites.

TABLE 1

EFFEGT OF PINE NEEDLE FRACTIONS ON THE UTERINE WEIGHT OF 21-DAY-OLD MICE

\begin{tabular}{|c|c|c|c|c|c|}
\hline $\begin{array}{l}\text { Test } \\
\text { ration }\end{array}$ & $\begin{array}{c}\text { No. of } \\
\text { mice }\end{array}$ & $\begin{array}{c}\text { Food consumption } \\
4 \text { days/mouse } \\
(\mathrm{g})\end{array}$ & $\begin{array}{c}\text { Av. body wt } \\
\text { gain }(+) \text { or loss }(-) \\
(g \mid \text { mouse })\end{array}$ & $\begin{array}{l}\text { Av. uterine } \\
\text { weight } \\
(m g)\end{array}$ & $\begin{array}{l}\text { Uterine } \\
\text { wt/body wt } \\
(\mathrm{mg} / \mathrm{g})\end{array}$ \\
\hline $\begin{array}{l}\text { Control } \\
\text { Volatile } 2: 1 \\
\text { Volatile } 3: 1 \\
\text { Acetone } 2: 1 \\
\text { Acetone } 1: 1 \\
\text { Aqueous } 2: 1 \\
\text { Aqueous } 1: 1\end{array}$ & $\begin{array}{r}25 \\
11 \\
8 \\
9 \\
10 \\
10 \\
10\end{array}$ & $\begin{array}{l}8 \cdot 0 \\
8 \cdot 8 \\
8 \cdot 8 \\
6 \cdot 8 \\
8 \cdot 8 \\
6 \cdot 0 \\
9 \cdot 2\end{array}$ & $\begin{array}{l}+3 \cdot 1 \\
+3 \cdot 5 \\
+2 \cdot 3 \\
-2 \cdot 6 \\
+1.5 \\
+0 \cdot 6 \\
+0.7\end{array}$ & $\begin{array}{c}14 \cdot 7 \\
13 \cdot 9 \\
10 \cdot 5^{*} \\
9 \cdot 1^{*} \\
12 \cdot 0 \\
7 \cdot 7^{*} \\
9 \cdot 6^{*}\end{array}$ & $\begin{array}{l}1 \cdot 00 \\
1.02 \\
0 \cdot 76^{*} \\
0.85 \\
0.95 \\
0 \cdot 64 \\
0.72 *\end{array}$ \\
\hline
\end{tabular}

* Significantly decreased, $P<0.05$.

TABLE 2

EFFECTS OF VARIOUS PINE NEEDLE FRACTIONS ON PREGNANCY IN MICE

\begin{tabular}{|c|c|c|c|c|c|}
\hline $\begin{array}{c}\text { Test } \\
\text { ration }\end{array}$ & $\begin{array}{c}\text { No. of } \\
\text { pregnant } \\
\text { mice }\end{array}$ & $\begin{array}{l}\text { No. of mice } \\
\text { giving birth }\end{array}$ & $\begin{array}{l}\text { Av. litter } \\
\text { size }\end{array}$ & $\begin{array}{l}\text { Total no. of } \\
\text { young dead } \\
\text { after birth }\end{array}$ & Remarks \\
\hline $\begin{array}{l}\text { Control } \\
\text { Volatile } 3: 1 \\
\text { Volatile } 4: 1\end{array}$ & $\begin{array}{l}9 \\
8 \\
7\end{array}$ & $\begin{array}{l}9 \\
8 \\
7\end{array}$ & $\begin{array}{r}9 \cdot 4 \\
10 \cdot 0 \\
6 \cdot 9\end{array}$ & $\begin{array}{r}2 \\
5 \\
10\end{array}$ & Partial resorptions \\
\hline Acetone $1: 1$ & 8 & 8 & $8 \cdot 0$ & 0 & \\
\hline Aqueous $1: 1$ & 8 & 4 & $5 \cdot 5$ & 11 & $\begin{array}{l}\text { Partial or complete } \\
\text { resorptions apparent in } \\
\text { six mice }\end{array}$ \\
\hline $\begin{array}{l}\text { Aqueous } 1: 1 \\
\text { (autoclaved) }\end{array}$ & 8 & 8 & $9 \cdot 8$ & 2 & \\
\hline
\end{tabular}

Feeding of the pine needle fractions began 3 to 4 days after mating.

For the experiment on embryonic growth and mortality, virgin female mice of 8 to 10 weeks old were mated and subsequently examined twice daily for the presence of vaginal plugs. The mice with plugs were put on the feed according to experimental designs outlined in Tables 2 and 3 . The results tabulated in Table 2 show that the acetone fraction had no effect on reproduction. The volatile fraction had a small effect on the development of the fetuses, but the 
aqueous fraction had a very detrimental effect. If the aqueous fraction was autoclaved the effect was lost.

The results of programmed feeding of the aqueous fraction, $1: 1$, show that the effect on pregnancy varied with duration of feeding (Table 3). Mice receiving the ration from 10 days before mating did not appear to be pregnant. Upon examining the uteri, there was evidence that pregnancy had occurred but that fetal development had been arrested. The uteri were hyperaemic or nodular, and the fetuses were presumed to have been completely resorbed. Some of the mice fed the ration beginning 1 or 4 days after mating showed signs of partial or complete resorption. The others carried their fetuses to term but their young were small and many were stillborn or died after birth. When the feeding started 10 or 15 days after mating, the chance of successful pregnancy was improved. Although the young appeared healthy, they weighed less than those on the basal feed.

TABLE 3

EFFEGT OF AQUEOUS PINE NEEDLE FRACTION ON PREGNANT MICE ON A PROGRAMMED FEEDING SGHEDULE

\begin{tabular}{c|c|c|c|c|c}
\hline $\begin{array}{c}\text { Date } \\
\text { feed } \\
\text { begun* }\end{array}$ & $\begin{array}{c}\text { No. of } \\
\text { mice } \\
\text { pregnant }\end{array}$ & $\begin{array}{c}\text { No. of } \\
\text { mice } \\
\text { giving birth }\end{array}$ & $\begin{array}{c}\text { Av. litter } \\
\text { size }\end{array}$ & $\begin{array}{c}\text { Total young } \\
\text { dead after } \\
\text { birth }\end{array}$ & $\begin{array}{c}\text { Av. wt }(g) \\
\text { of 2-day-old } \\
\text { young }\end{array}$ \\
\hline Controls & 16 & 16 & 9.9 & 4 & 1.75 \\
-10 & 12 & 0 & 8.0 & 9 & \\
-5 & 8 & 2 & 10.5 & 20 & 1.30 \\
+1 & 8 & 4 & 11 & 1.18 \\
+4 & 8 & 4 & 5.5 & 7 & 1.76 \\
+10 & 8 & 8 & 7.9 & 7 & 1.37 \\
+15 & 8 & 8 & 8.0 & 3 & \\
\hline
\end{tabular}

Mice received a 1:1 ration (see footnote to Table 1).

* - , Days before mating; + , Days after mating.

Allen \& Kitts (1961) and Cook \& Kitts (1964) reported that an agent present in pine needles suppressed growth of the uterus of immature mice and caused embryonic mortality. They suggested that the agent was antioestrogenic. Deem et al. (1959, as reported by Faulkner, 1968) indicated that consumption of pine needles by pregnant cows caused abortion or the birth of weak nonviable calves. The effect was lost when the needles were pelleted. These observations were found to be true with mice in our laboratory.

According to the results from this study, the agent which affects pregnancy is water-soluble and thermolabile. Apparently, the agent neither acts as a contraceptive nor affects fertilization and implantation. Disruption of pregnancy seems to occur during the stage when the placenta starts to grow. At that time, cell division and growth are rapid. The effect of the agent is much less severe when feeding is started late in pregnancy. Since the result was more severe the longer the mice were on the feed, the effect of the agent seems to be cumulative.

This study was supported by the Colorado Agricultural Experiment Station. 


\section{REFERENGES}

Allen, M. R. \& Kitts, W. D. (1961) The effect of yellow pine (Pinus Ponderosa Laws) needles on the reproductivity of the laboratory female mouse. Can. F. Anim. Sci. 41, 1.

Bruce, E. A. (1927) Astragalus serotinus and other stock-poisoning plants of British Columbia, Dominion of Canada. Bull. Dept Agric. Dom. Can. No. 88.

Cook, H. \& KrTTs, W. D. (1964) Anti-oestrogenic activity in yellow pine needles (Pinus ponderosa). Acta endocr, Copenh. 45, 33.

Emmens, G. W. (1969) Estrogens. In: Methods in Hormone Research. Ed. Ralph Y. Dorfman. Academic Press, London.

Faurkner, L. G. (1969) Pine needle abortion. In: Aborting Diseases of Livestock. Ed. L. G. Faulkner. Charles G. Thomas. Springfield, Illinois.

MacDonald, M. A. (1952) Pine needle abortion in range beef cattle. Range $M g m t, 5,150$.

Sakai, T., MaArse, H., Kepner, R. E., Jennings, W. G. \& Longhurst, W. M. (1967) Volatile components of Douglas fir needles. F. agric. Fd Chem. 15, 1070. 